УДК 339.166.8:658.8

DOI: https://doi.org/10.37320/2415-3583/13.7

Заячковська Г.А. кандидат економічних наук, доцент, доцент кафедри маркетингу та менеджменту, Хмельницький кооперативний торговельно-економічний інститут ORCID: https://orcid.org/0000-0001-8631-7268

Бухта C.B.

кандидат економічних наук, доцент кафедри маркетингу та менеджменту Хмельницький кооперативний торговельно-економічний інститут ORCID: https://orcid.org/0000-0002-4598-3667

\title{
МАРКЕТИНГОВІ ІНСТРУМЕНТИ СТИМУЛЮВАННЯ ІМПУЛЬСНИХ ПОКУПОК: ГРУПА «ПРОДОВОЛЬЧІ ТОВАРИ»
}

Статтю присвячено вивченню впливу маркетингових інструментів візуального мерчандайзингу на здійснення споживачами імпульсних покупок групи «продовольчі товари». Охарактеризовано зміст і структуру поняття «імпульсна покупка». Здійснено ранжування товарів-лідерів імпульсних покупок. За результатами масштабних маркетингових досліджень визначено, що група продовольчих товарів є оптимальною нішею впливу на здійснення імпульсних покупок. Емпіричне дослідження, проведене на базі торговельної мережі «СООР Україна», забезпечило підтвердження висунутих гіпотез. Встановлено стійку взаємозалежність між впливом візуального мерчандайзингу та здійсненням імпульсних покупок у роздрібних торговельних підприємствах. Визначено інструменти візуального мерчандайзингу, пріоритетні для використання у торговельній мережі “СООР Украӥна». Доведено, що застосування інструментів візуального мерчандайзингу є наріжним каменем формування конкурентних переваг та забезпечення ефективного попиту, тобто головної умови рентабельності бізнесу з ритейлу продуктів харчування; група «продовольчі товари» є оптимальною сферою здійснення імпульсних покупок.

Ключові слова: візуальний мерчандайзинг, імпульсні покупки, поведінка споживача, продовольчі товари.

Постановка проблеми. У сфері роздрібної торгівлі нашої держави функціонує більше 14 тис. магазинів «СООР Україна», які здійснюють реалізацію широ- кого асортименту продовольчих товарів і працюють за стандартами магазинів-маркетів [1]. Стійка тенденція до загострення конкуренції серед підприємств роз- 
дрібної торгівлі спонукає вивчати та впроваджувати інноваційні інструменти маркетингу для впливу на поведінку споживачів задля збільшення продажів продукції. Згідно з консолідованою інформацією брендингової агенції “Integer Group”, 90\%покупців здійснюють незаплановані покупки під час кожного відвідування магазину [3]. Вважаємо, що використання інструментів візуального мерчандайзингу здатне стимулювати здійснення імпульсних покупок i, як наслідок, максимізувати прибуток за рахунок збільшення продажів.

Аналіз останніх досліджень і публікацій. Причини здійснення імпульсних покупок мають поліфакторний характер, отже, перебувають у сфері наукових і практичних інтересів маркетологів, психологів, фахівців 3 продажів. Перебуваючи у ніші мерчандайзингу, дослідження імпульсних покупок розпочинається 3 осягнення фундаментальних положень А. Веллхоффа, Ж. Массона, Ф. Котлера та знаходить логічне продовження у працях У. Кіннана, Р. Колборна, Т. Моргана. $\mathrm{У}$ роботі над статтею використовувались результати досліджень $з$ проблеми таких науковців, як С. Карпова [14], Л. Василькевич [5], К. Петляк [9], В. Марченко [10]. 3 огляду на практично зорієнтований характер дослідження емпіричну базу для висновків, зроблених у статті, склали результати масштабних маркетингових досліджень, оприлюднених Міжнародною асоціацією маркетингу в ритейлі "Point-of-Purchase Advertising Institute" [11], брендинговою агенцією "Integer Group" [3], "Institut Français du Merchandising" [14], інформаційними ресурсами "CreditCards.com", "Brandongaille", а також дослідження, здійснені авторами на базі підприємств торговельної мережі «СООР Україна» [1].

Мета статті полягає у доведенні таких гіпотез: встановлення стійкої взаємозалежності між впливом візуального мерчандайзингу та здійснення імпульсних покупок у роздрібних торговельних підприємствах; доведення тези про те, що саме група «продовольчі товари» $\epsilon$ оптимальною сферою здійснення імпульсних покупок; визначення інструментів візуального мерчандайзингу, пріоритетних для використання у торговельній мережі «СООР Україна».

Виклад основного матеріалу дослідження. Охарактеризуємо базові терміни, якими будемо послуговуватися під час розкриття змісту дослідження. Французький інститут мерчандайзингу (“Institut Français du Merchandising”) визначає поняття мерчандайзингу як сукупність досліджень і прикладних методів, які застосовуються ритейлерами та виробниками задля підвищення рентабельності торгової точки та збільшення збуту шляхом постійної адаптації асортименту до вимог ринку й адекватного представлення товарів [14]. Візуальний мерчандайзинг - це «комплекс заходів, що проводяться у торговому залі та спрямовані на збільшення продажів і просування того чи іншого товару за допомогою їх спеціального розміщення, оформлення простору магазину та вітрин для того, щоб дати покупцеві максимум інформації про товари» [4, с. 129]. Візуальний мерчандайзинг пов'язаний із візуальними елементами представлення товарів у магазинах роздрібної торгівлі задля підвищення їх реалізації та стимулювання продажів.

Використання інструментів візуального мерчандайзингу базується на знанні психологічних особливостей поведінки споживачів у процесі прийняття рішення про купівлю товарів. Під поведінкою споживачів розуміємо «сукупність дій і вчинків інтелектуального, фізичного та психологічного характеру, які здійснюються під впливом факторів зовнішнього й внутрішнього середовищ особами і спрямовані безпосередньо на отримання й споживання товарів, послуг, ідей для задоволення власних потреб» [5]. Прийоми візуального мерчандайзингу, розроблені з орієнтацією на ситуацію споживання, стиль споживання та створення емоцій, сприяють імпульсним покупкам товарів.

Зміст дослідження скеровує нас до розгляду структури й змісту поняття «імпульсна покупка» (табл. 1).

Вважаємо, що група продовольчих товарів є однією 3 найкращих ніш для мотивації до здійснення імпульсних покупок.

Наші аргументи на користь цієї тези такі:

1) 3 психологічної точки зору їжа є найпростішим способом отримання задоволення, доступного споживачам різного матеріального статусу. Прикладом цього $\epsilon$ глибинна ідея змісту реклами «Кока-Коли», розробленої Енді Ворхолом: «Кока-Колу п’є кожен - від президента США до хлопчика-жебрака з ПАР» [13];

2) Покупцями продуктів є зазвичай жінки (згідно 3 дослідженнями, 85\% усіх споживчих витрат припадають саме на покупців-жінок). Жінки більшою мірою налаштовані на розмову 3 продавцем-консультантом, вони більш емоційні та більш схильні до імпульсних покупок. Так, «серед факторів, які можуть змусити придбати товар, для жінок найбільш значущими виявилися знижки, розпродажі і дегустація товару, також були відзначені порада продавця, яскрава упаковка і незвичайна викладка товару. Чоловіки не поділяють думки жінок щодо поради продавця і яскравої упаковки. Жоден 3 опитаних не відзначив ці чинники як значущі. Це перш за все пов'язано з тим, що чоловікам більшою мірою значима сама сутність, зміст продукту» [10].

Дослідження, проведене авторитетною трейдмаркетинговою асоціацією "РОРАI" [11], дає змогу здійснити ранжування товарів-лідерів імпульсних покупок (рис. 1).

Бажання зробити спонтанну покупку найчастіше виникає у покупців в магазинах самообслуговування. Це зумовлено природньою схильністю людини до можливості робити самостійний вибір та великим різноманіттям товарів, що впливає на глибинну внутрішню потребу у їжі як основі самозбереження. Саме тому реформа торгової мережі «СООР Україна», що серед іншого передбачає маркети як пріоритетну форму торговельного обслуговування, виглядає більш ніж переконливо. Суттєву роль при цьому відіграють заходи торгового маркетингу, зовнішній вигляд товару та його упаковки, заходи візуального мерчандайзингу.

Мотивами імпульсної покупки продовольчих товарів є такі:

- «Нарешті я це знайшов!»;

- «Зовсім забув, що це мені потрібно»;

- «Я навіть не підозрював, що мою проблему так легко вирішити за допомогою цього товару!»;

- «Куплю це заодно з іншим товаром, бо завтра мені це обов'язково знадобиться»;

- «Це мені подобається. І за ціною доступно»;

- «Я можу зробити собі подарунок»; 
Таблиця 1 - Структура і зміст поняття «імпульсна покупка»

IМПУЛЬСНА (СПОНТАННА, IMPULSE PURCHASE) ПОКУПКА

«Покупка товару, що здійснюється під впливом зовнішніх спонукальних чинників, рішення про яку покупець приймає безпосередньо в точці продажу» [6].

Імпульсні покупки жодним чином не можна вважати неусвідомленими, однак чітких планів стосовно придбання певних товарів покупець не має [3, с. 145]

\begin{tabular}{|c|c|c|}
\hline \multicolumn{3}{|c|}{ ВИДИ ІМПУЛЬСНИХ ПОКУПОК } \\
\hline Імпульсно запланована покупка & Імпульсно нагадувальна покупка & Імпульсно спонукальна покупка \\
\hline $\begin{array}{l}\text { Покупець прийняв рішення заздалегідь, } \\
\text { але його реалізація залежить від ціни, } \\
\text { часу, місця пропозиції та інших чинників. }\end{array}$ & $\begin{array}{l}\text { Покупка товарів, побачивши які, } \\
\text { покупець згадує про необхідність їх } \\
\text { придбання. }\end{array}$ & $\begin{array}{l}\text { Покупка товарів, які споживач вперше } \\
\text { бачить в магазині, але їх придбання } \\
\text { стимулюється бажанням спробувати і } \\
\text { пізнати їх [7]. }\end{array}$ \\
\hline
\end{tabular}
ХАРАКТЕРИСТИКА ТОВАРІВ ІМПУЛЬСНОГО ПОПИТУ

\begin{tabular}{|c|c|c|}
\hline 1) асоціація із задоволенням & $\begin{array}{l}\text { зовнішня привабливість, максимальні } \\
\text { емонстраційні можливості }\end{array}$ & $\begin{array}{l}\text { 3) невеликий розмір або можливість } \\
\text { поділу на частинки (фасовка порцій «на } \\
\text { пробу») }\end{array}$ \\
\hline $\begin{array}{l}\text { ПОКУПОК: } \\
\text { 1) за матеріалами агенції Brandongaille, } \\
\text { США [12] }\end{array}$ & \multicolumn{2}{|c|}{$\begin{array}{l}\text { Понад 40\% покупців витрачають на покупки більше, ніж планували. Більше } \\
\text { половини покупців у США (54\%) витрачають на імпульсні покупки \$100 і } \\
\text { більше, включаючи 20\%, які витрачають більше } \$ 1000 .\end{array}$} \\
\hline $\begin{array}{l}\text { 2) за матеріалами Міжнародної асоціації } \\
\text { маркетингу в ритейлі POPAI (Рoint-of- } \\
\text { Purchase Advertising Institute) [11] }\end{array}$ & \multicolumn{2}{|c|}{$\begin{array}{l}\text { Чітко заплановані покупки в середньому складають лише } 30 \% \text { загального обсягу } \\
\text { продажів, 8-10\% припадають на покупки альтернативні, } 60 \% \text { - на спонтанні чи } \\
\text { імпульсні. }\end{array}$} \\
\hline $\begin{array}{l}\text { ПОРТРЕТ ІМПУЛЬСИВНОГО } \\
\text { ПОКУПЦЯ [12] }\end{array}$ & \multicolumn{2}{|c|}{$\begin{array}{l}\text { - Самотні покупці здійснюють на 45\% більше імпульсних покупок, ніж одружені пари; } \\
\text { - найбільше імпульсних покупок відбувається в радісному і піднесеному настрої } \\
\text { (50\% серед жінок і 46\% серед чоловіків); смуток провокує жінок на покупки } \\
\text { частіше, ніж чоловіків (28\% проти 14\%); під впливом алкоголю імпульсні } \\
\text { покупки здійснюють } 13 \% \text { чоловіків і 5\% жінок; } \\
\text { - 75\% покупців відчувають себе щасливими після скоєння спонтанних покупок; } \\
\text { - 46\% чоловіків і } 52 \% \text { жінок шкодують щодо здійснених імпульсних покупок. }\end{array}$} \\
\hline $\begin{array}{l}\text { ФАКТОРИ ВПЛИВУ } \\
\text { ПОКУПКИ [3] }\end{array}$ & \multicolumn{2}{|c|}{$\begin{array}{l}\text { - Максимальна широта асортименту; } \\
\text { - можливість вибору; } \\
\text { - зовнішній вигляд, колір та форма упаковки; } \\
\text { - зовнішні споживчі властивості товару (зовнішній вигляд, запах, колір тощо); } \\
\text { - спеціальні заходи торгового маркетингу, що проводяться в місця продажу; } \\
\text { - технології мерчандайзингу. }\end{array}$} \\
\hline
\end{tabular}

\section{1. Готова їжа і кондитерські вироби}

2. Риба і морепродукти

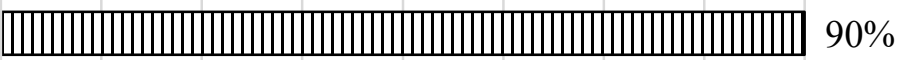

4. Чіпси, снеки

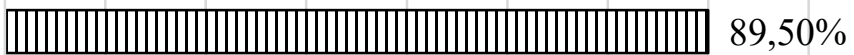

5.Напої в жестяних банках

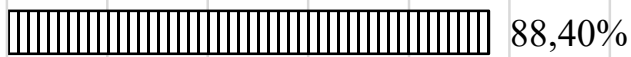

6. Супи
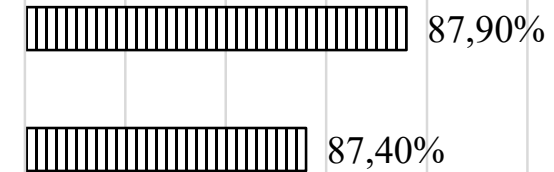

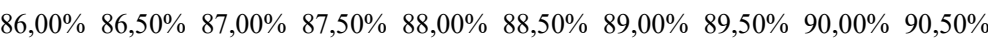

Рисунок 1 - Товари-лідери імпульсних покупок 
- «Як цікаво! Я куплю це, бо обожнюю пробувати щось нове»;

- «Як корисно! Я куплю це, тому що дбаю про своє здоров'я»;

- «Я нарешті досяг певного матеріального рівня, тому можу спокійно купити цей товар просто тому, що мені раптом захотілося».

В унісон $з$ цими мотивами покупців звучать фрази візуальної та аудіовізуальної реклами: «3 назва товару це легко!», «Купи назва товару! Ти заслужив (заслужила) на подарунок!», «Ти можеш собі це дозволити», «Назва товару - твоя мить насолоди!» тощо.

Аналіз публікацій з проблематики візуального мерчандайзингу та здійснення імпульсних покупок дав можливість визначити основні складові частини візуального мерчандайзингу, які рекомендується використовувати магазинам, що входять у торговельну мережу «СООР Україна»:

1) Візуально привабливий інтер'єр магазину впливає на формування його образу, залучення покупців та стимулює імпульсну купівлю товарів. Його оформлення має відповідати смакам та стилю життя покупців, формувати сприятливу атмосферу, щоб у покупців було бажання регулярно відвідувати магазин.

2) Макет магазину має значний вплив на торгову атмосферу, схему руху покупців, їх поведінку під час вибору товарів та ефективність збуту. Дослідження показують, що погано спланований макет магазину може спричинити психологічний дискомфорт у покупців, тому останні будуть утримуватися від повторних покупок. Так, в Україні перепланування традиційних гастрономів 3 торгівлею за прилавком під магазини самообслуговування привело до зростання роздрібних продажів на 15-20\%, а за відсутності жорсткої конкуренції в місті або районі - до 60\% [2]. Можливість самостійного вибору товарів $€$ найбільш значимим інструментом впливу на частоту імпульсних покупок.

3) Викладка товарів у торговельній залі, яка створює відмінну видимість товарів, є найкращим стимулом для імпульсних покупок. Розміщення товарів на передньому краї полиці стимулює спонтанні покупки, що особливо характерно для цукерок та шоколаду, тобто імпульсної категорії № 1. Для молочних продуктів, напоїв і багатьох інших товарів використовують систему гравітаційної подачі "Roller Track", що збільшує кількість спонтанних покупок та продажі у час пік до 20\% [8]. Правильно візуально виставлений і сегментований товар заохочує до здійснення покупки.

Імпульсні покупки стимулює комплексна викладка товару, тобто розміщення в одному місці взаємопов'язаних товарів. Так, товари можуть викладатися на основі тематичного зв'язку: поруч розміщуються всі товари, що стосуються приготування суші; або товари кожного виробника розташовуються окремо. Значимим фактором є розмаїття товарів. Коли людина бачить велику кількість товару, спрацьовує інстинкт споживання і вона робить спонтанну покупку, тому спокусливі товари слід розміщувати на видному місці та у великій кількості в торговельній залі.

До імпульсних місць належать полиці, що знаходяться на рівні очей і рук покупця (1,5 м від підлоги), вони зручні для сприйняття і забезпечують значну частку імпульсних покупок. Крім того, перед касами оформляють стенди з товарами імпульсного попиту, зокрема солодощами, жувальними гумками, напоями, бульйонними кубиками, сигаретами, які малопомітні у торговельній залі. Викладка перед касою (прикасова зона), коли покупці стоять у черзі й можуть приділити час вивченню товарів, стимулює зростання продажу товарів імпульсного попиту, що може становити від 7\% до $18 \%$ товарообігу [6].

4) Серед елементів візуального мерчандайзингу важливу роль відіграє колір, оскільки викликає у споживачів певні асоціації, відчуття відповідних емоцій та спонукає до конкретних дій. Його використовують для увиразнення відповідності товару очікуванням споживачів за функціональними, емоційними та іншими ознаками. Психологи виявили, що на виникнення імпульсу покупки впливає яскрава й приваблива упаковка, особливо жовтого, червоного та синього кольорів. Спонтанним покупкам також сприяє упаковка, яка зображує, наприклад, процес приготування їжі. Застосування кольору без урахування інших факторів може привести до зменшення цілеспрямованого впливу на поведінку споживачів і розсіювання їх купівельної активності.

5) Освітлення у внутрішньому просторі магазину сприяє створенню позитивної атмосфери продажу. Дослідження показують, що правильне освітлення може збільшити продажі товарів до 20\% [9]. Зони товарів імпульсного попиту розміщують у добре освітлених місцях, застосовуючи прийоми світлового дизайну. Різні рівні освітлення можуть безпосередньо впливати на час, який споживачі проводять в магазині, та привести до збільшення кількості куплених товарів.

6) Комфортна атмосфера в торговельній залі залежить від музичного фону, який має бути ненав'язливим та сприяти тривалішому перебуванню покупців у продуктовому магазині, що позитивно впливає на збільшення імпульсних покупок. На музику звертають увагу понад 70\% покупців, тому у час пік ставлять швидку музику, щоб люди здійснювали покупки у прискореному темпі.

7) Аромамаркетинг є сильним засобом впливу, який може викликати як позитивні, так і негативні емоції та асоціації. За його допомогою можна впливати на настрій покупців, викликати в їхній уяві яскраві образи та спонукати до тривалішого перебування в торговельній залі, уважнішого вивчення асортименту товарів i збільшення імпульсних покупок. У продовольчих магазинах, як правило, використовують аромати кави, какао, абрикосу та заварного крему, однак запах свіжоспеченого хліба та хлібобулочних продуктів або курки-гриль формують сильний імпульс до покупки. Приклад вдалого нарощення обсягів продукції власного виробництва та розміщення відкритих міні-пекарень у торговому залі маркету можемо спостерігати на підприємствах Тернопільської облспоживспілки «ТеКо Трейд».

- Бажаний ефект забезпечує ароматизація товарів, які не пахнуть. Так, ароматизація прилавків із копченостями у вакуумній упаковці може збільшити обсяг імпульсних покупок. Запах ванілі, шоколаду, какао, кави сприятиме продажам кондитерських виробів, розміщених у закритій скляній вітрині. Наявність унікального аромату в магазині може вдало вирізняти його 
серед інших подібних закладів та викликати спогади про нього, коли покупці відчувають цей запах.

Представляючи маркетингові інструменти, що сприятимуть здійсненню імпульсних покупок, ми наполягаємо на дотриманні етичних норм під час здійснення впливу на поведінку покупця: імпульсна покупка має принести радість та задоволення у процесі споживання товару.

Висновки. Застосування інструментів візуального мерчандайзингу $€$ наріжним каменем формування конкурентних переваг та забезпечення ефективного попиту, тобто головної умови рентабельності бізнесу
3 ритейлу продуктів харчування. Особливо значимим цей маркетинговий інструмент $\epsilon$ в ніші продажу товарів продовольчої групи. Врахування результатів здійсненого дослідження щодо характеристики поведінки споживачів та дотримання рекомендацій візуального мерчандайзингу дадуть змогу, на нашу думку, забезпечити підвищення рівня продажів.

Перспективи дослідницької роботи $з$ окресленого питання будуть скеровані у напрямах глибинної характеристики топ-товарів імпульсного попиту, статистики імпульсних покупок, портрету імпульсного покупця в реаліях українського бізнесу.

\section{Список використаних джерел:}

1. Ресторанний бізнес // Офіційний сайт Укркоопспілки. URL: http://www.coop.ua/torgivlya (дата звернення: 09.01.2020).

2. Мерчендайзинг - формирование импульса покупки. URL: https://psyfactor.org/merchan.htm (дата звернення: 05.02.2020).

3. Шалева О. Мерчандайзингові технології стимулювання імпульсних покупок у роздрібній торгівлі. URL: http://nbuv.gov.ua/UJRN/Torg_2018_23_26 (дата звернення: 05.04.2020).

4. Карпова С. Современный брендинг : монография. Москва : Палеотип, 2011. 188 с.

5. Василькевич Л. Соціально-економічна природа поведінки споживачів на ринку товарів i послуг. URL: http://www.economy.nayka.com.ua/?op=1\&z=621 (дата звернення: 12.03.2020).

6. Импульсная покупка. URL: http://www.marketch.ru/marketing_dictionary/marketing_terms_i/impulsnaya_pokupka (дата звернення: 22.03.2020).

7. Анализ запланированных и фактических покупок. URL: http://menedzhmenti.ru/mer/page291/index.html (дата звернення: 22.03.2020).

8. Ефективний мерчандайзинг - ключ до успіху в управлінні категорією. URL: https://psyfactor.org/merchan.htm (дата звернення: 02.04.2020).

9. Petljak K. The Role of Store Layoutand Visual Merchandising in Food Retailing. European Journal of Economics and Business Studies. 2016. P. 14.

10. Марченко В., Евченко М., Гуляев А. Исследование особенностей покупательского поведения мужской и женской аудитории. Молодой ученый. 2014. № 8(67). C. 528-531. URL: https://moluch.ru/archive/67/11396 (дата звернення: 09.07.2020).

11. Исследование POPAI. Покупки в магазинах. URL: http://www.popairussia.com/publishing/market_news/issledovanie popai_pokupki_v_magazinah_pechene (дата звернення: 15.07.2020).

12. Dramatic Impulse Buying Statistics. URL: https://brandongaille.com/18-dramatic-impulse-buying-statistics (дата звернення: 15.07.2020).

13. Духовность в банке супа и бутылке Coca-Cola. URL: http://www.cablook.com/inspiration/duhovnost-v-banke-supa-butylkecoca-cola (дата звернення: 15.07.2020).

14. IFM (Institut Français du Merchandising). URL: http://-ifm.asso.fr/site (дата звернення: 15.07.2020).

\section{References:}

1. Official site of Ukrkoopspilka. Restaurant business. Available at: http://www.coop.ua/torgivlya (accessed 9 January 2020).

2. Merchandising is the formation of a buying impulse. Available at: https://psyfactor.org/merchan.htm (accessed 9 February 2020).

3. Shaleva O. Merchandayzynhovi tekhnolohiyi stymulyuvannya impul'snykh pokupok u rozdribniy torhivli [Merchandising technologies to stimulate impulse purchases in retail]. Available at: http://nbuv.gov.ua/UJRN/Torg_2018_23_26 (accessed 5 April 2020).

4. Karpova S. (2011). Sovremennyy brending [Modern branding]. Moscow: Paleotype. (in Russian)

5. Vasil'kevich L. Sotsial'no-ekonomichna pryroda povedinky spozhyvachiv na rynku tovariv i posluh [Socio-economic nature of consumer behavior in the market of goods and services]. Available at: http://www.economy.nayka.com.ua/ ?op $=1 \& z=621$ (accessed 12 March 2020).

6. Impulse buying. Available at: http://www.marketch.ru/marketing_dictionary/marketing_terms_i/impulsnaya_pokupka (accessed 22 March 2020)

7. Analysis of planned and actual purchases. Available at: http://menedzhmenti.ru/mer/page291/index.html (accessed 22 March 2020).

8. Effective merchandising is the key to success in category management. Available at: https://psyfactor.org/merchan.htm (accessed 2 April 2020).

9. Petljak K. (2016). The Role of Store Layoutand Visual Merchandising in Food Retailing. European Journal of Economics and Business Studies, p. 14.

10. Marchenko V., Evchenko M., Gulyaev A. (2014). Issledovaniye osobennostey pokupatel'skogo povedeniya muzhskoy i zhenskoy auditorii [Research of the peculiarities of purchasing behavior of male and female audience]. Molodoy uchenyy, no. 8(67), pp. 528-531. Available at: https://moluch.ru/archive/67/11396 (accessed 9 July 2020).

11. POPAI research. Shopping in stores. Available at: http://www.popairussia.com/publishing/market_news/issledovanie_popai_ pokupki_v_magazinah_pechene (accessed 15 July 2020).

12. Dramatic Impulse Buying Statistics. Available at: https://brandongaille.com/18-dramatic-impulse-buying-statistics (accessed 15 July 2020).

13. Spirituality in a can of soup and a bottle of Coca-Cola. Available at: http://www.cablook.com/inspiration/duhovnost-v-bankesupa-butylke-coca-cola (accessed 15 July 2020).

14. IFM (Institut Français du Merchandising). Available at: http://-ifm.asso.fr/site (accessed 15 July 2020). 
Zaiachkovska Halyna, Bukhta Svitlana

Khmelnytskyi Cooperative Trade and Economic Institute

\section{MARKETING INSTRUMENTS TO ENCOURAGE IMPULSE PURCHASES: GROUP OF FOOD PRODUCTS}

The study is devoted to the research of the limits, opportunities, and ways of using marketing tools of visual merchandising for consumer impulse purchases. The group of "food products" was singled out as a subject of research. The content and structure of the concept of "impulse purchase" are characterized (types of impulse purchases, characteristics of impulse demand goods, characteristics and statistics of impulse purchases, portrait of impulsive buyer by gender and age characteristics are the most significant factors influencing impulse purchases). The multifactorial nature of impulse purchases by consumers is proved. The ranking of goods-leaders of impulse purchases is carried out. According to the results of consolidation of data presented in large-scale marketing research (International Retail Marketing Association Point-of-Purchase Advertising Institute, branding agency Integer Group, Institut Français du Merchandising, information resources CreditCards.com., Brandongaille) and research conducted by the authors on the basis enterprises of the trade network COOP Ukraine proved that the group of food products is the optimal niche of influence on the implementation of impulse purchases. The multifactorial nature of impulse purchases by consumers is proved. It is hypothesized that the most significant psychological motive in the irrational purchase of food is the desire to have fun, and the largest share of buyers who purchase food are women. Consolidated results of theoretical generalizations and empirical research confirmed the correctness of the hypotheses: a stable interdependence between the impact of visual merchandising and the implementation of impulse purchases in retail outlets; visual merchandising tools have been identified which are priorities for use in the COOP Ukraine retail network. It is proved that: 1) the use of visual merchandising tools is a cornerstone of the formation of competitive advantages and ensuring effective demand is the main condition for the profitability of the food retail business; 2) the group "food products" is the optimal area of impulse purchases.

Key words: visual merchandising, impulse purchases, consumer behavior, food products.

JEL classification: M30, M31, M39 